\title{
MEDICINAL USES, BIOLOGICAL AND PHYTOCHEMICAL PROPERTIES OF HELICHRYSUM FOETIDUM (L.) MOENCH. (ASTERACEAE)
}

\author{
ALFRED MAROYI* \\ Department of Botany, Medicinal Plants and Economic Development Research Centre, University of Fort Hare, Alice, South Africa. \\ Email: amaroyi@ufh.ac.za
}

Received: 17 April 2019, Revised and Accepted: 16 May 2019

\begin{abstract}
Helichrysum foetidum is a medicinal plant species with various medicinal applications among different ethnic groups in Africa, Asia, and Europe. This review was aimed at providing a critical appraisal of the existing medicinal uses, biological activities, and phytochemical components of $H$. foetidum. Literature search for information on medicinal uses, biological activities, and phytochemical components of $H$. foetidum was conducted using various online search engines such as Scopus, Google Scholar, Mendeley, and Web of Science. Additional information on these aspects was sourced from the university library. Literature studies revealed that $H$. foetidum is mainly used to induce trances and as herbal medicine against wounds, sores, dysmenorrhea, eye infections, influenza, and as a sedative. Phytochemical compounds identified from the species include chalcones, diterpenoids, flavanols, flavonoids, phenolics, phenols, and proanthocyanidins. Pharmacological studies revealed that $H$. foetidum extracts and compounds have antibacterial, antifungal, antiviral, antioxidant, protease-inhibiting, and cytotoxicity activities. There is a need for advanced phytochemical and pharmacological evaluations and clinical trials aimed at evaluating the therapeutic potential of $H$. foetidum in Africa, Asia, and Europe.
\end{abstract}

Keywords: Asteraceae, Ethnopharmacology, Helichrysum foetidum, Herbal medicine, Indigenous pharmacopoeias

(C) 2019 The Authors. Published by Innovare Academic Sciences Pvt Ltd. This is an open access article under the CC BY license (http://creativecommons. org/licenses/by/4. 0/) DOI: http://dx.doi.org/10.22159/ajpcr.2019.v12i7.33607

\section{INTRODUCTION}

In African traditional medicine, species of the genus Helichrysum Mill. (family Asteraceae or Compositae) are highly valued as sources of herbal medicines [1-15]. Some of the species which include H. nudifolium (L.) Less. and H. odoratissimum (L.) Sweet are reported to have commercial potential as ritual incense, sedative, and herbal medicine for colds and chest pains, with their essential oils having commercial potential as inhalant and aromatherapy [10-12]. The leaves, stems, and twigs of these two species are sold as herbal medicines in the informal herbal medicine markets in South Africa [14,16-18]. In tropical Africa, Helichrysum foetidum (L.) Moench., commonly called yellow everlasting or silvery lemon everlasting, is a valuable herbal medicine in the region $[19,20]$. Five synonyms, namely Anaxeton foetidum Gaertn., Gnaphalium argenteum Mill., Gnaphalium buchingeri Sch. Bip., Gnaphalium foetidum L., and Gnaphalium fruticans Schrank, are associated with the species [21-27]. The species is native to Burundi [28], Cameroon [29], Democratic Republic of Congo (DRC) [28,30], Equatorial Guinea [31], Eritrea [25], Ethiopia [25,28,32-39], Kenya [3,28], Malawi [5,26,28], Nigeria [28,40], Rwanda [41], São Tomé and Príncipe (Gulf of Guinea) [42], Somalia [27], South Africa [20,21,24,43,44], South Sudan [28,45], Sudan [28,45], Tanzania [28,46,47], Uganda [28,48], and Yemen $[28,49]$. H. foetidum has also been introduced in several countries throughout the world as an ornamental or medicinal plant species [50-62]. The species was introduced in Crimea [50], Hawaii [53,55,57,60], Spain [61], the Netherlands [51], and the UK [54] as an ornamental plant. $H$. foetidum was first recorded as naturalized in Portugal in 1868, and the species is currently categorized as a weed, established in natural or semi-natural communities [58]. In Spain, the species was introduced as an ornamental plant in Galicia and it was first recorded as naturalized in 1870 [59]. Research by Bujan [59] revealed that the species is now widespread as a weed and regarded as an important component of indigenous pharmacopoeia of several communities in the country [56]. Research by Wester [53] and Daehler [57] showed that $H$. foetidum was first recorded as naturalized in Hawaii in 1949. In Brazil, H. foetidum is naturalized in temperate grasslands, particularly swamp areas and on ecotone zones of thickets and semi-deciduous forests [62]. Based on literature records, H. foetidum is naturalized as a casual or invasive weed in Brazil, Hawaii, Portugal, and Spain [52,53,57,58-62].

H. foetidum is an annual or short-lived perennial shrublet, about $30 \mathrm{~cm}-150 \mathrm{~cm}$ in height $[21,24,44]$. The stems are erect, simple, robust, cylindrical, striated, and rarely branched near base. Leaves are alternate, sticky and aromatic, sessile, oblong-lanceolate, auriculate and clasping, roughly hairy above, and grey-woolly beneath [44]. The leaves are grouped at the stem base and wither at the time of flowering. $H$. foetidum is characterized by glossy, deep yellow to cream flower heads with several florets $[20,44]$. The species is a fire ephemeral which grows rapidly, flowers profusely and produces many fruits which have pappus bristles and several tiny seeds which are easily dispersed by wind [20]. These seeds are capable of persisting in the soil until conditions are conducive for germination. The current study is focusing on the medicinal applications of the species and its contribution to primary health care of local communities. Therefore, this review aims to provide a critical appraisal of the existing ethnomedicinal value, phytochemistry, and biological activities of compounds isolated from the species including $H$. foetidum crude extracts as well as exploring the potential of the species as herbal medicine.

\section{MEDICINAL USES OF H. FOETIDUM}

Major medicinal applications of different plant parts of $H$. foetidum based on literature records include the following (in descending order of importance): wounds, sores, induce trances, dysmenorrhea, eye infections, influenza, and as a sedative (Table 1 and Fig. 1). Smoke of different plant parts of $H$. foetidum is regarded as a rapid and effective means of inducing trances or causing hallucinogenic effects in South Africa [6,8,63-68]. Other minor medicinal applications of different plant parts of $H$. foetidum include uses as herbal medicine for herpes in Rwanda [41], pneumonia in Tanzania [69], snakebite antidote in the DRC [30], and tonsillitis in Spain [56]. H. foetidum together with other Helichrysum species such as H. aureonitens Sch. Bip., H. cymosum (L.) D. Don, H. nudifolium, H. odoratissimum, H. pedunculatum Hilliard 
Table 1: Medicinal uses of Helichrysum foetidum

\begin{tabular}{llll}
\hline Disease & Parts used & Country & References \\
\hline Dysmenorrhea & Whole plant & South Africa & {$[1,4,20,65,74-76]$} \\
Eye infections & Roots & Kenya and South Africa & {$[3,4,20,76,77]$} \\
Herpes & Whole plant & Rwanda & {$[41]$} \\
Induce trances & Whole plant & South Africa & {$[6,8,20,63-68,76]$} \\
Influenza & Leaves & Kenya and South Africa & {$[3,4,20,76]$} \\
Pneumonia & Leaves & Tanzania & {$[69]$} \\
Sedative & Leaves and stems & South Africa & {$[7,78]$} \\
Snakebite & Whole plant & DRC & {$[30]$} \\
Sores & Leaves & South Africa & {$[1,4,20,63,76,79-87]$} \\
Tonsillitis & Whole plant & Spain & {$[56]$} \\
Wounds & Leaves & South Africa, Spain, and Yemen & {$[1,20,56,63,75,76,79-81,83,84,88-90]$} \\
\hline
\end{tabular}

DRC: Democratic Republic of Congo

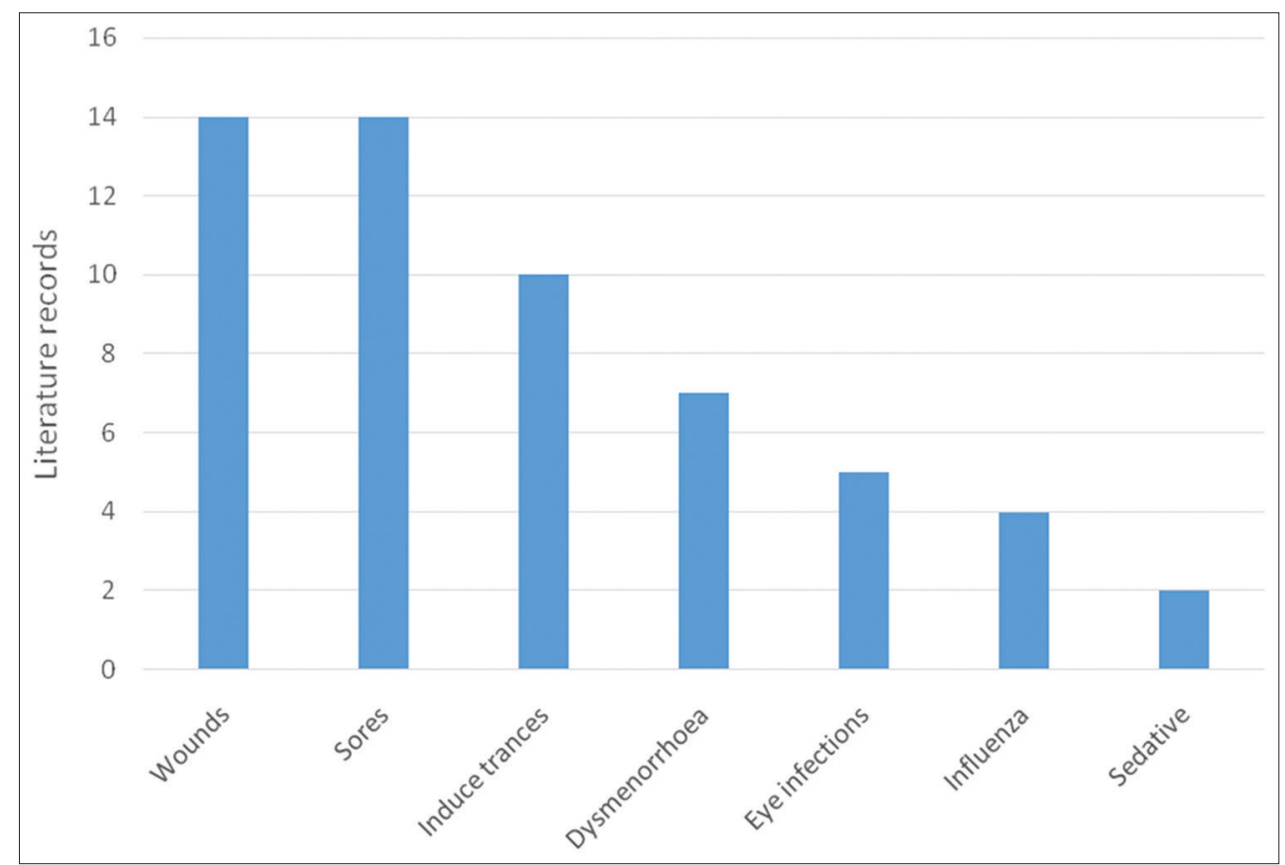

Fig. 1: Medicinal applications of Helichrysum foetidum derived from literature records

and B. L. Burtt, and H. petiolare Hilliard and B. L. Burtt are important medicinal plants used almost daily in South Africa [14]. Some of the Helichrysum species such as $H$. nudifolium and $H$. odoratissimum have recently become the focus of commercial development of health promoting and pharmaceutical products in South Africa [10-12]. The dynamic and adaptive usage of $H$. foetidum as herbal medicine is corroborated by the usage of different plant parts of the species as herbal medicine for tonsillitis and wounds in Spain [56]. These findings support the hypothesis that indigenous pharmacopoeias are influenced by the availability of exotic species in local communities as these systems are not static social institutions, but evolve overtime, with evidence of deletions and insertions of plants that compose it, with the addition of alien plants as sources of herbal medicines [70-73].

\section{PHYTOCHEMISTRY}

Many classes of nutritional and phytochemicals (Table 2) including flavanols, flavonoids, phenolics, phenols, and proanthocyanidins as well as classic nutrients and mineral elements have been identified and quantified [91,92]. Chalcones, flavonoids, and diterpenoids have so far been isolated and identified in $H$. foetidum flowers and leaves by Barrero et al. [93], Kakam et al. [94], and Malolo et al. [95] using gas chromatography-mass spectrometry, hydrogen nuclear magnetic resonance, and thin-layer chromatography (TLC) analyses (Table 3). Research by Fong et al. [96] revealed that 6'-methoxy-2',4, 4'-trihydroxychalcone inhibited Ca Ski cells at half maximal inhibitory concentration $\left(\mathrm{IC}_{50}\right)$ of $30.6 \mu \mathrm{M}$, and therefore, the compound has the ability to induce DNA damage, mitochondrial membrane disruption, and loss of cell membrane integrity. The chemical structures of isolated compounds are shown in Fig. 2.

\section{BIOLOGICAL ACTIVITIES}

The following biological activities have been reported from $H$. foetidum crude extracts and compounds isolated from the species: antibacterial [41,95,97,98], antifungal [95,98,99], antiviral [41], antioxidant [92], protease-inhibiting [95], and cytotoxicity [97] activities.

\section{Antibacterial activities}

Sindambiwe et al. [41] evaluated antibacterial activities of $80 \%$ ethanol whole plant extracts of $H$. foetidum using the liquid dilution method against Escherichia coli, Klebsiella pneumoniae, Proteus vulgaris, Pseudomonas aeruginosa, Salmonella paratyphi, Bacillus cereus, Mycobacterium fortuitum, Staphylococcus aureus, and Streptococcus pyogenes. The extract was active against Streptococcus pyogenes with minimum inhibitory concentration (MIC) value of $5 \mathrm{mg} / \mathrm{ml}$ [41]. Lourens et al. [97] evaluated antibacterial activities of leaf and stem chloroform: methanol (1:1) extracts of H. foetidum against Bacillus cereus, Staphylococcus aureus, Staphylococcus epidermidis, Klebsiella pneumoniae, and Pseudomonas aeruginosa using microdilution technique with ciprofloxacin as a positive control. The extract exhibited 
Table 2: Nutritional composition and other phytochemical of Helichrysum foetidum

\begin{tabular}{|c|c|c|c|}
\hline Composition & Values & Plant parts & References \\
\hline Acid detergent fiber (\%) & 38.2 & Leaves & {$[91]$} \\
\hline Calcium $(\%)$ & 1.3 & Leaves & [91] \\
\hline Cellulose digestibility (\%) & 51.2 & Leaves & [91] \\
\hline Flavanols & $13 \pm 2 \mathrm{mg} / \mathrm{g}$ dry extract as (-) epicatechin & Whole plant & [92] \\
\hline Flavonoids & $460 \pm 69 \mathrm{mg} / \mathrm{g}$ dry extract as rutin & Whole plant & [92] \\
\hline Magnesium (\%) & 0.4 & Leaves & [91] \\
\hline Moisture content $(\%)$ & 86.0 & Leaves & [91] \\
\hline Phosphorus (\%) & 0.4 & Leaves & [91] \\
\hline Potassium (\%) & 3.4 & Leaves & [91] \\
\hline Protein content (\%) & 18.7 & Leaves & [91] \\
\hline Total phenolics (\%) & 6.7 & Leaves & [91] \\
\hline Total phenols & $580 \pm 87 \mathrm{mg} / \mathrm{g}$ dry extract as gallic acid & Whole plant & [92] \\
\hline
\end{tabular}

Table 3: Phytochemicals isolated and characterized from Helichrysum foetidum

\begin{tabular}{|c|c|c|c|c|}
\hline Phytochemical & Extract & $\begin{array}{l}\text { Method of } \\
\text { characterization }\end{array}$ & Plant part & References \\
\hline \multicolumn{5}{|l|}{ Chalcones } \\
\hline 6'-methoxy-2',4, 4'-trihydroxychalcone & Methanol & GC-MS and H NMR & Flowers and leaves & {$[94,95]$} \\
\hline $6^{\prime}$-methoxy-2',4-dihydroxychalcone $-4^{\prime}-0-\beta$-D-glucoside & Methanol & GC-MS and H NMR & Flowers and leaves & {$[94,95]$} \\
\hline \multicolumn{5}{|l|}{ Diterpenoid } \\
\hline Kaur-16-en-18-oic acid & $\begin{array}{l}\text { Chloroform and } \\
\text { methanol }\end{array}$ & GC-MS, H NMR, and TLC & Flowers & [93-95] \\
\hline Apigenin & Methanol & GC-MS and H NMR & Flowers and leaves & {$[94,95]$} \\
\hline Apigenin-7-0- $\beta$-D-glucoside & $\begin{array}{l}\text { Chloroform and } \\
\text { methanol }\end{array}$ & GC-MS and H NMR & Flowers and leaves & {$[94,95]$} \\
\hline 7, 4'-dihydroxy-5-methoxy-flavanone & Methanol & GC-MS and H NMR & Flowers & {$[94,95]$} \\
\hline
\end{tabular}

GC-MS: Gas chromatography-mass spectrometry, TLC: Thin-layer chromatography, H NMR: Hydrogen nuclear magnetic resonance

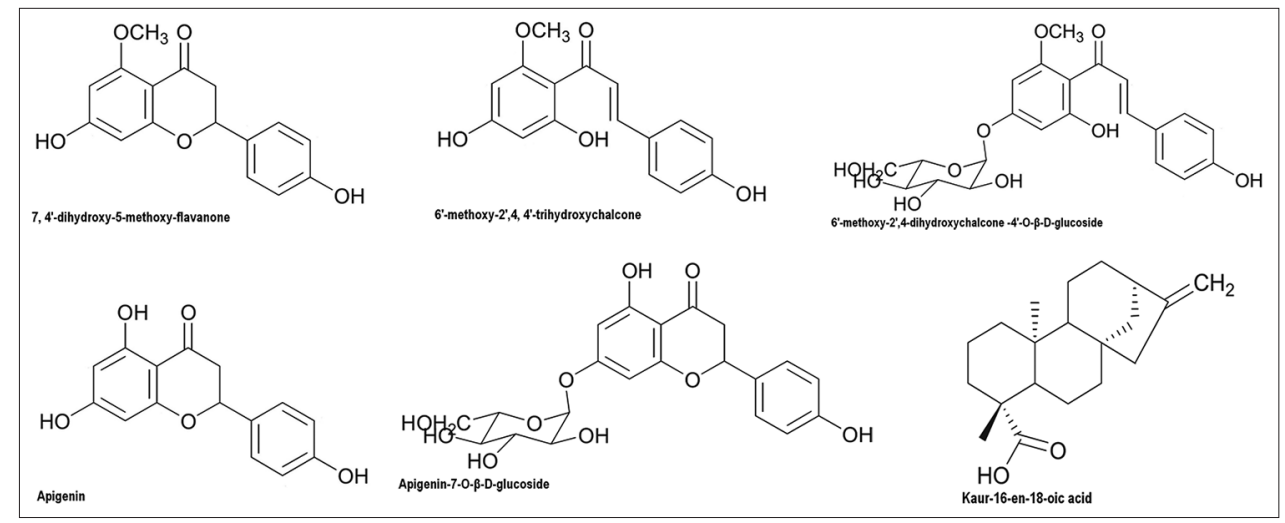

Fig 2: Chemical structures of compounds isolated from flowers and leaves of Helichrysum foetidum

activities against Bacillus cereus and Staphylococcus aureus with MIC values of $0.01 \mathrm{mg} / \mathrm{ml}$ and $0.5 \mathrm{mg} / \mathrm{ml}$, respectively, which were higher than $0.0003 \mathrm{mg} / \mathrm{ml}$ exhibited by the positive control [97]. Samie et al. [98] evaluated antibacterial activities of essential oils isolated from $H$. foetidum against Acinetobacter calcoaceticus, Bacillus cereus, Escherichia coli, Klebsiella pneumoniae, Micrococcus kristinae, Proteus vulgaris, Pseudomonas aeruginosa, Salmonella spp., Salmonella typhi, Serratia marcescens, Staphylococcus aureus, Staphylococcus epidermidis, and Streptococcus faecalis using the agar diffusion method and microdilution technique. The essential oils showed activities with MIC and minimum bactericidal concentration (MBC) values ranging from $3.8 \mathrm{mg} / \mathrm{ml}$ to $>7.5 \mathrm{mg} / \mathrm{ml}$ [98]. Samie et al. [98] evaluated the killing kinetics of Bacillus cereus, Proteus vulgaris, Staphylococcus aureus, Staphylococcus epidermidis, and Pseudomonas aeruginosa by the essential oils of $H$. foetidum. The essential oils were able to significantly reduce the number of bacterial cells after $3 \mathrm{~h}$ [98].
Malolo et al. [95] evaluated antibacterial activities of methanol flower and leaf extracts and compounds 7, 4'-dihydroxy-5-methoxyflavanone, $\quad 6^{\prime}$-methoxy-2',4, $4^{\prime}$-trihydroxychalcone, $\quad 6^{\prime}$-methoxy$2^{\prime}$,4-dihydroxychalcone-4'-0- $\beta$-D-glucoside, apigenin, apigenin-7-0- $\beta$-D-glucoside, and Kaur-16-en-18-oic acid isolated from $H$. foetidum against Bacillus subtilis using a fluorescence-based antibacterial growth inhibition assay with erythromycin as a positive control. The extracts showed significant and concentration-dependent growth inhibition of $85.4 \%$ at a concentration of $1 \mathrm{mg} / \mathrm{ml}$ and $21.8 \%$ at a concentration of $0.1 \mathrm{mg} / \mathrm{ml}$. All the compounds exhibited notable growth inhibition range of $75.0 \%-85.0 \%$ against Bacillus subtilis at a concentration of $1 \mathrm{mg} / \mathrm{ml}$ [95].

\section{Antifungal activities}

Samie and Nefefe [99] evaluated antifungal activities of essential oils isolated from $H$. foetidum against Fusarium oxysporum, 
F. nygamai, F. proliferatum, F. verticillioides, and $F$ graminearum using the agar diffusion method and microdilution technique. The essential oils showed activities with zone of inhibition of $10 \mathrm{~mm}$ against $F$. graminearum and $F$. nygamai, and zone of inhibition of $15 \mathrm{~mm}$ against $F$. oxysporum. The MIC values against tested fungi ranged from $0.5 \mathrm{mg} / \mathrm{ml}$ to $>7.5 \mathrm{mg} / \mathrm{ml}$ while minimum fungicidal concentration (MFC) values against all tested fungi ranged from $1.0 \mathrm{mg} / \mathrm{ml}$ to $>7.5 \mathrm{mg} / \mathrm{ml}$ [99]. Samie and Nefefe [99] evaluated the rate of kill of $H$. foetidum essential oils by determining the fungal cell death time against $F$. oxysporum, $F$. nygamai, $F$. proliferatum, $F$. verticillioides, and $F$ graminearum. The essential oils were able to kill the cells at different rates varying from $48 \%$ to $100 \%$ after 2 days of experimentation [99]. Samie et al. [98] evaluated antifungal activities of essential oils isolated from $H$. foetidum against Candida albicans, Candida glabrata, Candida krusei, Candida parapsilosis, Candida tropicalis, and Cryptococcus neoformans using the agar diffusion method and microdilution technique. The essential oils showed activities with MIC values ranging from $0.06 \mathrm{mg} / \mathrm{ml}$ to $7.5 \mathrm{mg} / \mathrm{ml}$ and MFC values ranging from $1.9 \mathrm{mg} / \mathrm{ml}$ to $>7.5 \mathrm{mg} / \mathrm{ml}$ [98]. Samie et al. [98] evaluated the killing kinetics of Candida albicans, Candida krusei, Candida parapsilosis, and Cryptococcus neoformans by the essential oils of H. foetidum. The essential oils were able to substantially decrease the number of fungi cells within a day [98]. Malolo et al. [95] evaluated antifungal activities of methanol flower and leaf extracts and compounds 7, 4'-dihydroxy5-methoxy-flavanone, $\quad 6^{\prime}$-methoxy-2',4, $\quad 4^{\prime}$-trihydroxychalcone, $6^{\prime}$-methoxy-2',4-dihydroxychalcone-4'-0- $\beta$-D-glucoside, apigenin, apigenin-7-0- $\beta$-D-glucoside, and Kaur-16-en-18-oic acid isolated from $H$. foetidum against Cladosporium cucumerinum using bioautography on silica gel plates with amphotericin B as a positive control. The extracts exhibited activities by showing the development of inhibition zones on the bioautography plates. All the compounds exhibited notable growth inhibition ranging from $56.0 \%$ to $70.0 \%$ against $C$. cucumerinum at a concentration of $1 \mathrm{mg} / \mathrm{ml}$ [95].

\section{Antiviral activities}

Sindambiwe et al. [41] evaluated antiviral activities of aqueous and $80 \%$ ethanol whole plant part extracts of $H$. foetidum using the method of $50 \%$ end point titration technique (50\% EPPT) assay against herpes simplex virus type 1 (HSV 1), measles virus strain Edmonston A (MV-EA), Semliki Forest virus A7 (SF A7), and vesicular stomatitis virus T2 (VSV T2). The extract exhibited virucidal activities against HSV 1 and SF A7 [41].

\section{Antioxidant activities}

Tirillini et al. [92] evaluated the antioxidant activities of methanol whole plant part extracts of $H$. foetidum using 2,2'-azino-bis(3-ethylbenzthiazoline-6-sulphonic acid assay, 1,1-diphenyl2-picrylhydrazyl free radical scavenging, ß-carotene/linoleic acid assay, scavenging of hydrogen peroxide (HRPO test), superoxide anion scavenging test, and hypochlorous acid scavenging (taurine test). The extract exhibited activities with $\mathrm{IC}_{50}$ values ranging from $0.5 \mu \mathrm{g}$ to $34.0 \mu \mathrm{g}$ [92].

\section{Protease-inhibiting activities}

Malolo et al. [95] evaluated the protease-inhibiting activities of methanol leaf extracts and compounds 7, 4'-dihydroxy-5methoxy-flavanone, $\quad 6^{\prime}$-methoxy-2',4, $\quad 4^{\prime}$-trihydroxychalcone, $6^{\prime}$-methoxy-2',4-dihydroxychalcone-4'-0- $\beta$-D-glucoside, apigenin, apigenin-7-O- $\beta$-D-glucoside, and Kaur-16-en-18-oic acid isolated from $H$. foetidum using a fluorescence resonance energy transfer protease pepsin inhibition assay. The extract exhibited pepsin protease inhibition of $37.4 \%$ and $35.6 \%$ at $50 \mu \mathrm{g} / \mathrm{ml}$ and $25 \mu \mathrm{g} / \mathrm{ml}$, respectively. The compounds $\quad 6^{\prime}$-methoxy-2',4-dihydroxychalcone-4'-O- $\beta$-D-glucoside and apigenin-7-0- $\beta$-D-glucoside exhibited pepsin protease inhibition of $37.4 \%$ and $46.3 \%$ at $50 \mu \mathrm{g} / \mathrm{ml}$, respectively [95].

\section{Cytotoxicity activities}

Lourens et al. [97] evaluated cytotoxicity activities of leaf and stem chloroform: methanol (1:1) extracts of $H$. foetidum using the sulforhodamine B assay against transformed human kidney epithelial (Graham) cells, MCF-7 breast adenocarcinoma, and SF-268 glioblastoma cells. The MCF-7 cells were more sensitive toward the extracts than either the Graham or SF-268 cells exhibiting $24.9 \%$ cell growth at a concentration of $0.1 \mathrm{mg} / \mathrm{ml}$, implying potential cytotoxicity [97].

\section{CONCLUSION}

The current review highlighted the medicinal uses, phytochemistry, and pharmacological activities of $H$. foetidum. The most studied pharmacological activities are antibacterial and antifungal activities. Correlating the pharmacological studies of $H$. foetidum with its medicinal uses, it is clear that the diverse biological activities identified so far are directly or indirectly associated with a wide range of physiological processes which offer protection against both growth of undesirable bacterial, fungal, and free radicals. There is no doubt that there are still some gaps where current knowledge could be improved, focusing on validating ethnomedicinal uses of $H$. foetidum through detailed phytochemical and pharmacological studies. There is also a need for experimental animal studies, randomized clinical trials, and target organ toxicity studies involving $H$. foetidum and its compounds.

\section{ACKNOWLEDGMENTS}

I would like to express my gratitude to the National Research Foundation, South Africa and Govan Mbeki Research and Development Centre, University of Fort Hare for financial support to conduct this study.

\section{AUTHOR'S CONTRIBUTIONS}

The author declares that this work was done by the author named in this article.

\section{CONFLICTS OF INTEREST}

The author declares that he has no conflicts of interest.

\section{REFERENCES}

1. Watt JM, Breyer-Brandwijk MG. The Medicinal and Poisonous Plants of Southern and Eastern Africa. Edinburgh: E \& S Livingstone; 1962.

2. Gelfand M, Mavi S, Drummond RR, Ndemera B. The Traditional Medical Practitioners in Zimbabwe: His Principles of Practice and Pharmacopoeia. Gweru: Mambo Press; 1985.

3. Kokwaro J. Medicinal Plants of East Africa. Nairobi: Kenya Literature Bureau; 1993

4. Hutchings A, Scott AH, Lewis G, Cunningham AB. Zulu Medicinal Plants: An Inventory. Pietermaritzburg: University of Natal Press; 1996.

5. Morris B. Chewa Medical Botany: A Study of Herbalism in Southern Malawi. London: International African Institute; 1996.

6. Arnold TH, Prentice CA, Hawker LC, Snyman EE, Tomalin M, Crouch NR, et al. Medicinal and Magical Plants of Southern Africa: An Annotated Checklist. Pretoria: National Botanical Institute; 2002.

7. Van Wyk BE, Gericke N. Peoples' Plants: A Guide to useful Plants of Southern Africa. Pretoria: Briza Publications; 2007.

8. Lourens AC, Viljoen AM, van Heerden FR. South African Helichrysum species: A review of the traditional uses, biological activity and phytochemistry. J Ethnopharmacol 2008;119:630-52.

9. van Wyk BE. A review of Khoi-San and Cape Dutch medical ethnobotany. J Ethnopharmacol 2008;119:331-41.

10. Van Wyk BE. The potential of South African plants in the development of new medicinal products. S Afr J Bot 2011;77:812-29.

11. Van Wyk BE. A review of commercially important African medicinal plants. J Ethnopharmacol 2015;176:118-34

12. Van Wyk BE. A review of African medicinal and aromatic plants. In: Nefati M, Najjaa H, Máthé A, editors. Medicinal and Aromatic Plants of the World Africa. Dordrecht: Springer; 2017. p. 19-60.

13. Moteetee A, Van Wyk BE. The medical ethnobotany of Lesotho: A review. Bothalia 2011:41:209-28.

14. Van Wyk BE, Oudtshoorn BV, Gericke N. Medicinal Plants of South Africa. Pretoria: Briza Publications; 2013.

15. Van Wyk BE, Gorelik B. The history and ethnobotany of Cape herbal teas. S Afr J Bot 2017;110:18-38.

16. Williams VL, Balkwill K, Witkowski ET. A lexicon of plants traded in the Witwatersrand umuthi shops. Bothalia 2001;31:71-98.

17. Dold AP, Cocks ML. The trade in medicinal plants in the Eastern Cape province, South Africa. S Afr J Sci 2002;98:589-97. 
18. Botha J, Weiersbye IM. Ethnobotanic and forage uses of plants on mine properties in the Witwatersrand basin gold fields, South Africa. In: Fourie A, Tibbett M, Wiertz J, editors. Mine Closure. Perth: Australian Centre for Geomechanics; 2010. p. 325-42.

19. Svoboda KP, Greenaway RI. Lemon scented plants. Int J Aromather 2003;13:23-32.

20. Swelankomo N. Helichrysum foetidum (L.) Moench; 2005. Available from: http://pza.sanbi.org/helichrysum-foetidum. [Last accessed on 2019 Feb 11].

21. Hilliard OM. Gnaphaliinae. In: Leistner OA, editor. Flora of Southern Africa: Asteraceae. Pretoria: National Botanical Institute; 1983. p. 1-135.

22. Beentje HJ. Compositae part 2. In: Beentje HJ, Smith SA, editors. Flora of Tropical East Africa. London: Crown Agents for Overseas Governments and Administration; 2002. p. 1-315.

23. Beentje H, Jeffrey C, Hind DJ. Compositae part 3. In: Beentje HJ, Smith SA, editors. Flora of tropical East Africa. London: Kew Royal Botanic Gardens; 2005. p. 547-869.

24. Germishuizen G, Meyer NL. Plants of Southern Africa: An Annotated Checklist. Strelitzia. Vol. 14. Pretoria: National Botanical Institute; 2003.

25. Hedberg I, Friis I, Edwards S. Flora of Ethiopia and Eritrea. Addis Ababa: The National Herbarium; 2004.

26. Burrows JE, Willis CK. Plants of the Nyikaplateau: An Account of the Vegetation of the Nyika National Parks of Malawi and Zambia. Pretoria: Southern African Botanical Diversity Network Report No. 31, SABONET; 2005.

27. Thulin M. Flora of Somalia. Vol. 3. London: Royal Botanic Gardens, Kew; 2006.

28. Friis I, Vollesen K. Flora of the Sudan-Uganda Border Area East of the Nile: I. Catalogue of Vascular Plants. Biologiske Skrifter. Vol. 51. Copenhagen: The Royal Danish Academy of Sciences and Letters; 1998.

29. Neba NE. Degradation of useful plants in Oku tropical montane cloud forest, Cameroon. Int J Biod Sci Manage 2006;2:73-86.

30. Chifundera K. Contribution to the inventory of medicinal plants from the Bushi area, South Kivu province, democratic republic of Congo. Fitoterapia 2001;72:351-68.

31. Velayos M, Cabezas F, Barberá P, de la Estrella M, Aedo C, Morales R, et al. Preliminary checklist of vascular plants of Bioko Island (Equatorial Guinea). Bot Complut 2013;37:109-33

32. Tadesse M. The physiognomy and floristic composition of the vegetation on some degraded hillsides in southern Wello, Ethiopia. Opera Bot 1993;121:661-71.

33. Demel T, Granström A. Soil seed banks in dry Afromontane forests of Ethiopia. J Veg Sci 1995;6:777-86.

34. Demel T. Seedling populations and regeneration of woody species in dry Afromontane forests of Ethiopia. For Ecol Manage 1997;98:149-65.

35. Demel T. The impact of clearing and conversion of dry Afromontane forests in to arable land on the composition and density of soil seed banks. Acta Oecologica 1997;18:557-73.

36. Demel T, Granström A. Seed viability of Afromontane tree species in forest soils. J Trop Ecol 1997;13:81-95.

37. Demel T. Soil seed bank at an abandoned Afromontane arable site. Feddes Repert 1998;109:161-74.

38. Demel T. Seed and regeneration ecology in dry Afromontane forests of Ethiopia: II. Forest disturbances and succession. Trop Ecol 2005;46:45-64.

39. Yineger H, Kelbessa E, Bekele T, Lulekal E. Floristic composition and structure of the dry Afromontane forest at Bale Mountains National Park, Ethiopia. Sinet Ethiop J Sci 2008;31:103-20.

40. Omoigui ID, Aromose OS. Nature of ergastic substances in some Nigerian Asteraceae. Bayero J Pure Appl Sci 2012;5:160-7.

41. Sindambiwe JB, Calomme M, Cos P, Totté J, Pieters L, Vlietinck A, et al. Screening of seven selected Rwandan medicinal plants for antimicrobial and antiviral activities. J Ethnopharmacol 1999;65:71-7.

42. Figueiredo E, Paiva J, Stévart T, Oliveira F, Smith GF. Annotated catalogue of the flowering plants of São Tomé and Príncipe. Bothalia 2011;41:41-82.

43. Goldblatt P, Manning JC. Cape Plants: A Conspectus of the Cape Flora of South Africa. Strelitzia. Vol. 9. Cape Town: National Botanical Institute; 2000

44. Manning JC, Goldblatt P. Plants of the Greater Cape Floristic Region 1: The Core Cape Flora. Strelitzia. Vol. 29. Cape Town: South African National Biodiversity Institute; 2012.

45. Darbyshire I, Kordofami M, Farag I, Candiga R, Pickering H, Helen A. The Plants of Sudan and South Sudan: An Annotated Checklist. London: Kew Publishing, Kew; 2015.

46. Hemp A. An ethnobotanical study on Mt. Kilimanjaro. Ecotropica 1999;5:147-65.
47. Legère $\mathrm{K}$, Maganga $\mathrm{S}$, Mkwan'hembo $\mathrm{P}$. Vidunda people and their plant names. Afr Asia 2004;4:115-41

48. Cunningham AB. People, Park and Plant Use: Recommendations for Multiple-use Zones and Development Alternatives around Bwindi Impenetrable National Park, Uganda. People and Plants Working Paper 4. Paris: UNESCO; 1996.

49. Ibrahim HM, Al-Quhbi HA, Murshed AA, Al-Gifri AN. Influence of the African paleotropical floristic categories on the flora of highaltitude mountains in Yemen: Case study of Jabal An-NabiShuáyb, Sana'a (capital of Yemen). Phytol Balcanica 2018;24:75-85.

50. Osipova EA. The introduction of certain species of Helichrysum into the Crimea. Rastitel Resursy 1970;6:445-8.

51. Wijnands DO. The Botany of the Commelins: A Taxonomical, Nomenclatural and Historical Account of the Plants Depicted in the Moninckxatlas and in the Four Books by Jan and Caspar Commelin on the plants in the Hortus Medicus Amstelodamensis 1682-1710. Rotterdam: AA Balkema; 1983.

52. Rasbach H, Rasbach K, Bennert HW. New records and cytological results for the fern flora of Madeira. Br Pteridol Soc Fern Gazette 1990;13:391-5.

53. Wester L. Origin and distribution of adventive alien flowering plants in Hawaii. In: Stone CP, Smith CW, Tunison JT, editors. Alien Plant Invasions in Native Ecosystems of Hawaii. Honolulu: University of HI Cooperative National Park Resources Study Unit; 1992. p. 99-155.

54. Morris S. Legacy of a Bishop (Part 2): The flowers of Fulham Palace Gardens introduced 1675-1713. Garden Hist 1993;21:14-23.

55. Wagner WL, Herbst DR, Sohmer SH. Manual of the Flowering Plants of Hawaii. Bishop Museum Special Publication 83. Honolulu: University of Hawaii Press and Bishop Museum Press; 1999.

56. González-Hernández MP, Romero R, Rodríguez-Guitián M, Rigueiro A. Medicinal use of some plants in Galicia (NW Spain). Acta Hort 2004;629:63-75

57. Daehler CC. Upper-montane plant invasions in the Hawaiian Islands: Patterns and opportunities. Perspect Plant Ecol Evol Syst 2005;7:203-16.

58. Almeida JD, Freitas H. Exotic naturalized flora of continental Portugal: A reassessment. Bot Complut 2006;30:117-30.

59. Buján MI. The alien flora of Galicia (Iberian Northwest). Bot Complut 2007:31:113-25.

60. Benitez DM, Belfield T, Loh R, Pratt L, Christie AD. Inventory of Vascular Plants of the Kahuku Addition, Hawaii Volcanoes National Park. Technical Report 157. Mānoa: Pacific Cooperative Studies Unit, University of Hawaii; 2008.

61. Fagúndez J. Effects of wind farm construction and operation on mire and wet heath vegetation in the Monte Maior SCI, North-West Spain. Mires Peat 2008;4:1-12.

62. Barcelos L, Heiden G. First record of Helichrysum foetidum (L.) Moench. (Asteraceae, Gnaphalieae) for South America. Check List 2017;13:331-4.

63. Gerstner J. A preliminary checklist of Zulu names of plants with short notes. Bantu Stud 1938;12:321-42.

64. Hulme M. Wild Flowers of Natal. Pietermaritzburg: Shuter and Shooter; 1954.

65. Batten A, Bokelmann H. Wild Flowers of the Eastern Cape Province. Cape Town: Books of Africa; 1966.

66. De Smet PA. Some ethnopharmacological notes on African hallucinogens. J Ethnopharmacol 1996;50:141-6.

67. Schutles RE, Hofmann A, Rätsch C. Plants of the Gods: Their Sacred, Healing and Hallucinogenic Powers. Rochester: Healing Arts Press; 2001.

68. Pennacchio M, Jefferson LV, Havens K. Uses and Abuses of PlantDerived Smoke: Its Ethnobotany as Hallucinogen, Perfume, Incense and Medicine. Oxford: Oxford Press; 2010.

69. Shangali CF, Zilihona IJ, Mwang'ingo PL, Nummelin M. Use of medicinal plants in the Eastern Arc mountains with special reference to the Hehe ethnic group in the Udzungwa mountains. J East Afr Nat Hist 2008;97:225-54

70. Maroyi A. Ethnomedicinal uses of exotic plant species in South-central Zimbabwe. Indian J Trad Knowl 2018;17:71-7.

71. Semenya SS, Maroyi A. Exotics plants used therapeutically by Bapedi traditional healers for respiratory infections and related symptoms in the Limpopo province, South Africa. Indian J Trad Knowl 2018;17:663-71.

72. Maroyi A. Phytochemical and ethnopharmacological review of heteropyxis natalensis. Asian J Pharm Clin Res 2019;12:8-15.

73. Maroyi A. Lanneaschimperi: Review of its botany, medicinal uses, phytochemistry and biological activities. Asian J Pharm Clin Res 2019;12:31-6. 
74. Steenkamp V. Traditional herbal remedies used by South African women for gynaecological complaints. J Ethnopharmacol 2003;86:97-108.

75. Reddy D. The Phytochemistry and Antimicrobial Activity of Selected Indigenous Helichrysumspecies. MSc Dissertation. Johannesburg: University of the Witwatersrand; 2007.

76. Quattrocchi U. CRC World Dictionary of Medicinal and Poisonous Plants: Common Names, Scientific Names, Eponyms, Synonyms and Etymology. London: CRC Press; 2012.

77. Pendota SC, Grierson DS, Afolayan AJ. An ethnobotanical study of plants used for the treatment of eye infections in the Eastern Cape province, South Africa. Pak J Biol Sci 2008;11:2051-3

78. Stafford GI, Pedersen ME, van Staden J, Jäger AK. Review on plants with CNS-effects used in traditional South African medicine against mental diseases. J Ethnopharmacol 2008;119:513-37.

79. Hutchings A. Zulu Medicinal Plants. Pietermaritzburg: University of Natal Press; 1996.

80. Lourens AC, Reddy D, Bașer KH, Viljoen AM, Van Vuuren SF. In vitro biological activity and essential oil composition of four indigenous South African Helichrysum species. J Ethnopharmacol 2004;95:253-8.

81. Steenkamp V, Mathivha E, Gouws MC, van Rensburg CE. Studies on antibacterial, antioxidant and fibroblast growth stimulation of wound healing remedies from South Africa. J Ethnopharmacol 2004;95:353-7.

82. Swartz VG. Phytochemical Studies of Helichrysum patulum. MSc Dissertation. Cape Town: University of the Western Cape; 2006.

83. Mabona U. Antimicrobial Activity of Southern African Medicinal Plants with Dermatological Relevance. MSc Dissertation. Johannesburg: University of the Witwatersrand; 2013.

84. Mabona U, Van Vuuren SF. Southern African medicinal plants used to treat skin diseases. S Afr J Bot 2013;87:175-93.

85. Tayade SK, Dhale DA, Patil DA. Psychoactive drugs of plant origin: Lessons and potentials. J Ethnobiol Trad Med Photon 2013;118:340-51.

86. Matanzima Y. Quantitative and Qualitative Optimization of Antimicrobial Bioactive Constituents of Helichrysumcymosum using Hydroponics Technology. MSc Dissertation. Cape Town: Cape Peninsula University of Technology; 2014.

87. Suntar I. The medicinal value of Asteraceae family plants in terms of wound healing activity. Fabad J Pharm Sci 2014;39:21-31.
88. Roberts M. Indigenous Healing Plants. Johannesburg: Southern Book Publishers; 1990.

89. Grierson DS, Afolayan AJ. An ethnobotanical study of plants used for the treatment of wounds in the Eastern Cape, South Africa. J Ethnopharmacol 1999;67:327-32.

90. Hussein S, Dhabe A. Ethnobotanical study of folk medicinal plants used by villagers in Hajjah district, Republic of Yemen. J Med Plants Stud 2018;6:24-30.

91. Waterman PG, Choo GM, Vedder AL, Watts D. Digestibility, digestioninhibitors and nutrients of herbaceous foliage and green stems from an African montane flora and comparison with other tropical flora. Oecologia 1983;60:244-9.

92. Tirillini B, Menghini L, Leporini L, Scanu N, Marino S, Pintore G, et al. Antioxidant activity of methanol extract of Helichrysum foetidum moench. Nat Prod Res 2013;27:1484-7.

93. Barrero AF, Arteaga P, Herrador MM. Ent-Kaurenediterpenoids from Helichrysum foetidum. Fitoterapia 1998;69:83.

94. Kakam AM, Franke K, Ndom JC, Dongo E, Mpondo TN, Wessjohann LA. Secondary metabolites from Helichrysum foetidum and their chemotaxonomic significance. Biochem Syst Ecol 2011;39:166-7.

95. Malolo FA, Bissoue Nouga A, Kakam A, Franke K, Ngah L, Flausino $\mathrm{O}$ Jr., et al. Protease-inhibiting, molecular modeling and antimicrobial activities of extracts and constituents from Helichrysum foetidum and Helichrysum mechowianum (compositae). Chem Cent J 2015;9:32.

96. Fong HY, Abd Malek SN, Yee HS, Karsani SA. Helichrysetin induces DNA damage that triggers JNK-mediated apoptosis in Ca ski cells. Pharmacogn Mag 2017; 13:607-12.

97. Lourens AC, Van Vuuren SF, Viljoen AM, Davids $H$, Van Heerden FR. Antimicrobial activity and in vitro cytotoxicity of selected South African Helichrysum species. S Afr J Bot 2011;77:229-35.

98. Samie A, Nefefe T, Gundidza M, Mmbengwa V, Magwa M, Mtshali MS. Antimicrobial activities and time kill profiles of five essential oils from Southern Africa against selected bacterial and fungal organisms. Afr J Pharm Pharmacol 2012;6:3086-95.

99. Samie A, Nefefe T. Antifungal activities of essential oils from Southern African medicinal plants against five Fusarium species. J Med Plant Res 2012;6:465-78. 